\title{
Violence, (In)security and Human Rights in Latin America
}

\author{
Gastón Chillier and Silvia Varela
}

\begin{abstract}
This article examines the relationship between violence, insecurity and human rights in Latin America. It explores the context in which debates on citizen security emerged, the challenges that this context presented for human rights defenders and the strategies they have adopted in response to these challenges. The authors argue that current debates cannot be understood in isolation from the continent's long legacy of violence and repression. Security agencies still reproduce authoritarian structures and practices of impunity. 'Dual societies' prevail, in which the privileged see the job of the police as protecting them from the poor, who are stigmatised as criminals. Such views engender reactionary responses to insecurity that deepen segregation and victimisation. The authors outline a broader approach to citizen security based on inclusive policies protecting the rights of all citizens, premised on human rights as a condition of citizen security.
\end{abstract}

\section{Introduction}

Over the past two decades, rates of crime in Latin America and the Caribbean have increased dramatically. ${ }^{1}$ However, post-transitional states have generally failed to reform their security and justice institutions to enable them to confront these problems effectively and according to the rule of law. Fanned by the media's almost obsessive focus on crime stories, the question of insecurity has quickly risen to the top of the regional agenda, consistently topping polls on Latin American citizens' concerns. ${ }^{2}$ Although this widespread fear is often disproportionate compared with actual crime figures, it has prompted calls for hardline responses, which states have usually heeded. Institutional violence - the illegal repressive actions that security agencies have carried out in the name of fighting crime - has thus become one of the most common sources of human rights violations in post-authoritarian Latin America.

Conceptual debates on security in the continent have mirrored these developments. The notion of citizen security, coined in the $1990 \mathrm{~s}$ in contrast to the concept of national security, reflected a shift in focus away from threats to the state towards threats to public and social order posed by both the rise in crime and the public's fear of crime (Neild 1999: 2), as well as growing concerns about institutional violence. While there is an ongoing discussion about the precise meaning of this concept, what is relevant for the purposes of this article is that it opens up a discussion about the multiple factors that generate crime and violence and places responsibility for security in the hands of multiple actors, not merely security agencies (Dammert and Zúñiga 2007).

This article will seek to shed light on the dynamics between violence, insecurity and human rights in contemporary Latin America. The first section will examine the context in which the concept of citizen security emerged. We will argue that many of the problems associated with contemporary institutional violence are the consequences of unresolved legacies of the military regimes that ruled most Latin American countries for much of the twentieth century. The second section will discuss these challenges and the ways in which human rights groups have responded to them. We will contest the view that security is incompatible with human rights, arguing that this assumption fails to engage with the complexity of the problem. In contrast, the third 
section will outline a human rights approach to citizen security, based on broad policies that promote inclusion, protect the rights of all social sectors and view security problems as a systemic issue. The final section will illustrate the ways in which human rights advocates have used regional institutional mechanisms to implement this approach and win national political and legal battles.

\section{Authoritarian legacies and the failure to reform security agencies after democratic transitions}

The levels of crime that Latin America has seen since the 1980 s are a relatively new phenomenon, but the continent has a long legacy of violence, repression and fear (Koonings and Krujit 1999: 2) rooted in profound social inequalities. The contemporary problems of citizen security cannot be understood in isolation from this authoritarian legacy, since many of its long-term effects still plague Latin American societies more than two decades after the return of civilian rule.

\subsection{The legacy from national security doctrines}

During the Cold War, superpower competition for geopolitical power and influence profoundly affected developing nations. In many Latin American countries, a succession of military coups toppled democratically elected civilian governments. The new regimes developed National Security Doctrines (NSD), which put the military in charge of national development and public order and legitimised systematic human rights violations in the name of combating 'internal ideological enemies' (Neild 1999: 3). Under the NSD, the police were controlled by the military; they were abusive, often corrupt, and widely feared. Their mission was not to protect citizens but to support the political regime, and since they did not need public legitimacy to operate effectively, accountability mechanisms were practically nonexistent (Neild 1999).

Democratic transitions in Latin America have tended to focus on military reforms and civilmilitary relations, neglecting to transform the culture and practices of the police forces (Ales $e t$ al. 2004: 696). In addition to being abusive, security agencies were poorly equipped, underfunded and lacked training; therefore, they were ill-prepared to deal with the rise in crime of the 1980s and 1990s. The combination of authoritarian practices and inefficiency resulted in public distrust in the police, and, faced with increasing public outrage about insecurity, some governments resorted to re-engaging the armed forces in policing tasks. ${ }^{3}$ But even in countries that have held on to their hard-won restrictions on military intervention in internal security matters, such as Argentina, the legacy of military rule still determines the way the police forces approach crime. This is evidenced by the persistence of semi-military policing models (Chevigny 1999: 40-50), which share the rigid, vertical, hierarchical structures of the armed forces, as well as their resistance to any form of external control (Ales et al. 2004: 595).

Semi-military policing models support the view that 'criminals' are 'enemies' that must be eliminated, and this view legitimises abhorrent practices by the security forces. The logic of security agencies is often to shoot first and ask questions later, and summary executions - often masked as confrontations with criminal suspects - are commonplace. Thus, the abuse of deadly force is widespread in Latin America. In poor urban areas, it is seen as a means to manage ordinary crime (Chevigny 1999: 53).

\subsection{The persistence of undemocratic policing in democratic states}

The glaring contradiction between the notion of democracy and the authoritarian approach to policing described above begs the question: Why have these deeply undemocratic practices continued long after the end of military rule? One reason is that police forces in Latin America have rarely undergone processes of 'vetting' to assess the aptitude of individual members for public employment - especially in terms of their respect for human rights - and remove repressive elements (Duthie 2007: 17). Consequently, 'many law enforcement officials who have to deal with common crimes are the same ones who were previously asked to fight subversion, and they are accustomed to fulfilling their tasks with tactics and methods imposed in dictatorial times' (Méndez 1999: 21-2).

Such abusive officers have thrived largely thanks to the prevalence of systems of impunity throughout the criminal justice system (Chevigny 1999: 57-9) in most of the continent. From a human rights perspective, this is one of 
the gravest failings of democratisation processes. The Inter-American Commission on Human Rights (IACHR) defines impunity as 'the overall lack of investigation, prosecution, capture, trial and conviction of those responsible for the violation of rights protected by the American Convention' (Altolaguirre 2003: 4).

The cycle of impunity begins inside the police forces. The esprit de corps generated by the military structures inherited from authoritarianism has acted as a sort of protection racket, allowing corruption to flourish. ${ }^{4}$ Yet internal disciplining mechanisms are nonexistent or opaque. 'Petty' corruption - illegal actions carried out by individual officers for personal gain - is often overlooked by superiors. 'Structural' corruption, which is not the result of an individual's deviation, but consists of illegal actions promoted and motivated by security agencies' institutional objectives (Ales et al. 2004: 596-7), is actively encouraged. Put differently, 'structural' corruption is part of the 'set of routines (legal and illegal) that the police assumes as "its job" and through which it controls crime' (Ales et al. 2004: 602). An example of this type of corruption is the common practice of inventing non-existent crimes to justify the arrest and trial of innocent and vulnerable people in order to meet detention quotas and appear efficient (Ales et al. 2004).

At the judicial level, not much energy goes into prosecuting corrupt or abusive police officers. Convictions are rare, and even then sentences are lenient. The police have many ways of obstructing investigations, such as planting weapons on victims and tampering with the evidence. Even when cases make it to court, proceedings are often opaque and, therefore, receive little publicity. In some cases, like in Brazil, Colombia and Chile, the police are not even subject to ordinary justice but are tried in military courts, whose procedures are even more obscure and rarely result in convicting police officers (Chevigny 1999: 57-9).

\subsection{Insecurity for all, security for some}

The persistence of brutal police practices and systems of impunity is, ultimately, underpinned by the unequal social order that characterises most Latin American societies. The transition from military to civilian-led government has often not been enough to change this, and the actions of the police continue to reproduce this underlying social order (Chevigny 1995). This explains, at least in part, why hardline policies are so popular. Violent crime predominantly affects the poor and marginalised sectors, among them young people, immigrants from bordering countries and those living in emergency neighbourhoods. In Argentina, for example, 43 per cent of the murders committed in the city of Buenos Aires in 2005 took place in the south. This area, which is home to 30.7 per cent of the city's population, houses 60.2 per cent of the population whose basic needs are not met. ${ }^{5}$ Yet the middle and upper classes see crime as a problem that mostly plagues them, and for which the poor are to blame (Pinheiro 1999: 5).

These societies, in which only some citizens enjoy citizenship $^{6}$ rights and security as yet another unequally distributed good, have been termed 'uncivil democracies' (Neild 1999: 6) or ‘democracies without citizenship' (Pinheiro 1999: 2). The defining trait of such uncivil democracies is the clear disjuncture that exists between democracy 'on paper' and the practice of law enforcement.

\section{Citizen security and human rights: the challenges for activists}

The complex scenario described above has presented human rights organisations working on the issue of citizen security with a series of challenges. Two are particularly relevant to our analysis: the first is related to the historical role of human rights groups vis-à-vis the state; the second has to do with the political debate on the causes and cures of insecurity and violence.

\subsection{From preventing abuses to building state capacity}

In Argentina, the human rights movement gained momentum during the military dictatorship (1976-83), when dozens of women would gather at the Plaza de Mayo, in downtown Buenos Aires, carrying pictures of their loved ones and demanding to know their whereabouts. Following the collapse of the military regime, activists focused on two objectives: investigating the fate of the thousands abducted during the dictatorship and later prosecuting members of the armed and security forces that had taken part in human rights violations during that time (Jelin 1995). This focus on investigating and punishing abuses committed by state officials that is, on the limits of state power - was a 
pattern common to rights defenders in most authoritarian states.

While the above concerns persisted after the return of democracy, the focus of human rights groups broadened in line with political changes. In the 1990s, activists became alarmed by the dramatic increase in cases of police brutality, corruption and arbitrary detentions that accompanied rising crime rates. Moreover, the fear of insecurity, combined with violent policing and a poorly functioning criminal justice system, made abuse of pre-trial detention a widespread and socially acceptable practice in Latin America. In many countries, 70-80 per cent of detainees have not been convicted (Méndez 2003: 23). Across the continent, inmates in chronically overcrowded prisons endure poor health conditions, sexual violence and regular massacres in response to the frequent riots and uprisings (Pinheiro 1999: 4).

Human rights groups continue to defend the victims. Yet, since citizen security and human rights are issues that deeply affect democratic governance, it became clear that they could not be addressed by focusing exclusively on limiting state power. Thus, from the 1990s, human rights organisations have faced a new, fundamental challenge: how to continue denouncing state abuse while also advocating for the state to develop security and justice institutions that abide by the rule of law and international human rights standards. A few Latin American human rights organisations, such as the Centre for Legal and Social Studies (CELS) in Argentina, the Institute for Legal Defence (IDL) in Peru, and Viva Río in Brazil, embraced this challenge and began to address 'the function, as well as the behaviour, of the state' (ICHRP 2003).

There are some inherent tensions in this nascent role of 'critical engagement', as Neild (1999) points out. For example, it is more difficult for human rights advocates to promote controls on police actions than it is to engage with complex institutional reforms, since often changes happen at the level of police management where human rights activists have little access (Neild 1999: 18-19). Nevertheless, this 'emerging dual role' has helped activists address a related challenge that stems from the fact that the targets of state violence have changed. As Juan Mendez observes, it is no longer political adversaries that suffer torture, extra judicial executions and forced disappearances at the hands of the police and the military. Nowadays, victims are usually anonymous young men and women from poor areas whose victimisation does not make headline news or stir up international sympathies (Méndez 1999: 19-20). Moreover, since most victims of police abuse are believed to have engaged in some kind of illegal behaviour, human rights groups that focus only on the limits of state power leave themselves open to accusations that they are 'defending the criminals' (ICHRP 2003: 38).

\subsection{Contesting the dominant discourse}

The view that human rights activists work for criminals and against society is rooted in a widespread discourse that pits order against human rights and calls for a permanent state of emergency. This logic is underpinned by a rationale of war against chaos, which, consistent with the military approach to policing described previously, legitimises restricting citizens' rights and penalising the poor. Countering this widespread discourse has been one of the toughest challenges for human rights groups since the return of democracy.

The notion that human rights must be sacrificed to achieve security is deeply flawed on several accounts. First, the idea of achieving security through lawlessness is absurd, as Chevigny argues. The use of torture to extract confessions is a case in point. Not only does this result in the violation of human rights and the conviction of innocent people, but it also means that crimes are not adequately investigated and culprits remain free. Eventually, citizens lose faith in the criminal justice system (Chevigny 1999: 60).

Second, the idea is inaccurate. There is no conclusive evidence to prove that hardline policies reduce crime rates. The case of $\mathrm{El}$ Salvador, which has one of the highest homicide rates in the world, is illuminating. In 2003, the government implemented a series of highly publicised hardline, or mano dura, policies to curb crime and violence. When crime rates did not go down, they developed super mano dura policies. The prison population increased, but crime figures continued to rise; the homicide rate in El Salvador is currently 46 homicides per 100,000 inhabitants, which qualifies as endemic (Kliksberg 2008). On the other hand, there is a 
direct correlation between the implementation of hardline policies and the incidence of human rights violations. A 2006 study on the impact of these policies reported that 'crime has risen, gangs have grown more complex and professional, human rights violations have increased, particularly against the young [and] the prison situation has got worse [...] all of which has aggravated institutional weakness and threatened the rule of law' (cited in Garber 2008: 14-15).

\section{A human rights approach to citizen security}

In general, the various proposals for dealing with insecurity revolve around the management of coercive power, arguing for more or less intensity or regulation in the use of force. However, this is only one dimension of the problem, the depth of which is often lost in media and political analysis.

In contrast, an analysis of crime and institutional violence from a human rights perspective draws attention to the fact that the problems of citizen security not only affect the right to noninterference but also involve basic issues regarding relationships among citizens, between citizens and institutions, and among the institutions themselves. A broad notion of citizen security must aim to guarantee the conditions for the full enjoyment of collective, as well as individual, rights.

This approach does not mean inaction in the face of crime and violence. On the contrary, it means the active rejection of reductionist and authoritarian views. It implies making the most of the capacities and experience of other public institutions, apart from those traditionally responsible for public order, to formulate and implement security polices. Crucially, it involves developing inclusive security policies that protect the rights of all citizens and promote greater social integration, instead of protecting the rights of certain sectors at the expense of the rights of others and encouraging segregation and victimisation. At its most basic, an inclusive approach to citizen security should aim to control violence and reconstruct the bonds of citizenship.

\subsection{Controlling violence}

An inclusive approach to citizen security acknowledges the pressing issue of violence but calls for the recognition that crime is only one element of the problem. Institutional violence also poses a serious risk to the lives and integrity of citizens, and debates and policies on citizen security must not lose sight of this.

Thus, policies designed to control violence must start by acknowledging that modern security agencies are both part of the problem of violence and part of the solution. Consequently, they must consider the ways in which security agencies influence the social circulation of violence to avoid the reproduction of violent dynamics in the management of conflicts.

In order to control institutional violence and transform the security sector so it is compatible with democracy, security agencies need to undergo comprehensive reforms. These reforms entail rethinking the governance and practices of police forces, the ways in which they relate internally and to other institutions, and their links with civil society. The excessive autonomy of the forces must be curtailed and political control cemented as a means to increase transparency. The idea is not merely to keep strict controls on police behaviour but to generate new practices and a more professional culture. The success of police reforms must not only be measured in terms of crime reduction, real or perceived, but also with regards to the police's ability to operate within the bounds of the law (Garber 2008: 22).

Needless to say, for democratic police reforms to be successful and durable it is essential to combat impunity effectively. This is not only necessary to curb institutional violence in the continent, but also a condition for the consolidation of democracy (Altolaguirre 2003: $3)$. In other words, the rule of law can only be fully realised if and when impunity is tackled at every level - from dismantling the structures that enable and perpetuate corruption among police forces, to guaranteeing access to information, to countering the apathy of the administration of justice.

\subsection{Reconstructing citizenship bonds}

Reactionary approaches to insecurity not only foster more violence, but they also promote spatial segregation within cities, effectively turning certain areas associated with specific social sectors into ghettoes (Pires do Rio Caldeira 2000). An example of such policies is a crime prevention plan that the Argentine government 
adopted in response to increased public demand for security. ${ }^{8}$ The plan was implemented in the three villas de emergencia (slums) with the highest levels of crime, where elements of organised crime were known to operate. The three villas were effectively subjected to a military siege, with over 1,000 officers deployed around their perimeter to control the points of entry and exit, turning every resident of the villas into a virtual criminal suspect (CELS 2004). This kind of spatial segregation, common to all of Latin America, contributes to the stigmatisation of excluded social sectors as 'dangerous classes', which generates a fear of the 'other' among the privileged that justifies calls for hardline policies, as discussed above.

In contrast, a broad, inclusive approach to citizen security highlights the need to develop policies that tackle crime without deepening social exclusion. To this end, this approach contemplates actions that seek to broaden citizenship as a powerful integrating tool. This means focusing on crime prevention rather than merely its punishment. It means developing integral polices that involve not only security agencies but also civil society and local actors. It implies incorporating a social policies perspective into the way we think about security - ranging from employment and labour policies to those related to public space, social bonds and health.

\section{Citizen security in the Inter-American Human Rights System}

Just as the transitions to democracy brought new challenges and opportunities for human rights defenders at home, regional human rights mechanisms evolved considerably after the return of civilian rule. The new context offered new possibilities for activists, who have honed their advocacy strategies accordingly.

\subsection{Standard setting}

During the dictatorships, human rights groups looked to the Inter-American System for the Protection of Human Rights (particularly its two main institutions for the protection and promotion of human rights, the Inter-American Commission on Human Rights (IACHR) and the Inter-American Court of Human Rights) as a means to exert pressure on authoritarian governments. The first cases the system resolved involved forced disappearances, massacres and extra-judicial executions. With the advent of democracy, and in the face of the constant failure of national safeguard mechanisms, protecting victims of human rights abuses remained a priority. Yet, in the new democratic context, international legal instruments began to provide not only a last resort for protection, but also a source of principles on basic rights that aimed to promote and guide processes of institutional reform and democratic consolidation (CELS 2008: 41). In other words, the Inter-American System's opinions, cases, and reports began to be interpreted in a way that generated standards and imposed a series of positive obligations on states regarding the use of force, interrogations, searches, pre-trial detention, the differences between police and military functions and equal access to justice, among other issues.

The Bulacio case - a 17-year-old boy who was randomly arrested and died after being injured by police officers in Buenos Aires - was the first time the IACHR focused on the repressive policies of the Argentine state after the end of the dictatorship; its illegal means of social control (such as arbitrary mass detentions, or razzias); torture and deaths in custody; the complicity of the judiciary in police brutality; and the violation of the rights of children (CELS 2008: 182).

In the Bulacio case, the IACHR ruling addressed both the state's responsibility regarding the abuse of rights and its duty to implement institutional police reforms to prevent further abuses (CELS 2008: 186-7). The ruling brought hope to Bulacio's relatives, and it imposed unavoidable obligations on the Argentine state (CELS 2008: 189). This paradigmatic case highlighted the potential of using regional legal mechanisms to implement human rights standards nationally. However, it also highlights the limits of such strategies; five years after the ruling, Argentina has paid financial reparations as instructed, but it has yet to investigate and punish those responsible for Bulacio's illegal detention and death, and to fully change the laws and practices that condoned them (Tiscornia 2008).

\subsection{International policy advocacy}

Recently, some human rights groups have begun to seek innovative ways to place human rights at the centre of regional debates on citizen security. In 2005, a coalition of human rights organisations ${ }^{9}$ 
working on citizen security in the region joined forces to improve civil society's strategies in the framework of the Inter-American System. The coalition resolved that a key step to bring a human rights perspective to the regional debate on citizen security - which focused on issues such as the modernisation of the police institution but often neglected to consider the needs of the most vulnerable - was to involve the IACHR in the discussion. To this end, coalition members researched and compiled current human rights standards, based on decisions by regional and international bodies, on issues related to citizen security in Latin America. The three resulting documents were presented at a hearing with the IACHR in October 2005. Based on these documents, the IACHR agreed to commission a Report on Citizen Security and Human Rights in the Hemisphere (currently under way) to serve as a guide for Latin American states in their development of security policies respectful of human rights.

Meanwhile, the Organization of American States (OAS) announced the First Meeting of Ministers Responsible for Public Security in the Americas, which would take place in October 2008. This conference was to produce a declaration and a plan of action on citizen security in the Americas. The coalition deemed it necessary to take part in this process - and also urged the IACHR to do so - to expand its work promoting regional human rights standards to the OAS.

Members of the coalition were allowed to take part in the conference as observers. Prior to the conference, they analysed the official declaration ${ }^{10}$ and issued a joint statement ${ }^{11}$ in which they noted the positive aspects of the official declaration and made several recommendations. The statement from civil society organisations was published on the conference website and issued to participants alongside the official declaration.

\section{Conclusion}

This article has focused on the relationship between violence, insecurity and human rights in Latin America. It has examined the context in which the debates on citizen security emerged and the challenges that this scenario posed for human rights activists; their responses to these challenges and the strategies they have adopted using international institutional mechanisms.
While the triumph of democracy after decades of military rule brought high hopes for Latin America, in many ways the rule of law has not been consolidated. Post-transitional countries have focused on curbing their armies, with varying degrees of success, but security agencies continue to reproduce an approach to policing learned from the military regimes - violent and unaccountable, designed to quell dissent at any cost. When crime figures began to rise rapidly in the 1980s and 1990s, security forces were unprepared to respond democratically without the use of violence and coercion.

Undemocratic practices, such as summary executions and torture, have spread to endemic levels in Latin America, shielded behind systems of impunity that operate at every level of the criminal justice system. The question is why these systems of impunity have not been dismantled, decades after democratisation and despite the adoption of numerous human rights treaties and norms. We have argued that this is largely due to the prevalence of 'dual societies' in most of Latin America, characterised by vast inequalities between different social sectors, which democracy has done little to remedy. In these societies, the privileged see the job of the police as protecting them from the poor, who are stigmatised as criminals. As long as police violence and impunity affect mostly the poor, the privileged will continue to turn a blind eye to their egregious human rights violations.

There are practical reasons for breaking this cycle of violence and impunity, as well as reasons of principle. Hardline policies seek to allay the fear of insecurity of the privileged sectors, but they have not been proven to reduce the levels of crime. They have, however, reinforced social exclusion and stigmatisation, mostly among poor young males. While the relationship between exclusion and delinquency is complex, and beyond the scope of this article, it is obvious that this is no prescription for crime prevention.

In short, the view that rights must be sacrificed to guarantee security not only generates ineffective policies, but it comes at a great cost to our societies. As Rachel Neild (1999) notes,

... the failure to deepen democracy and the rule of law and extend citizenship rights across all social sectors shakes public 
confidence in the police and judicial system, weakens the rule of law and increasingly undermines support for democracy.

(Neild 1999: 6)

Against this narrow view, this article has put forward a broader approach to citizen security to match a broader notion of citizenship. This

\section{Notes}

1 Citing the WHO, Kliksberg (2008) notes that rates of homicides in Latin America have doubled in the last quarter of a century. In 1980 the average annual rate of homicides was 12.5 per 100,000 inhabitants; in 2006 it was 25.1.

2 The latest Latinobarometro poll shows that in many Latin American countries, crime and public safety is seen as the most important problem facing citizens; see: www.latinobarometro.org/docs/INFORME_ LATINOBAROMETRO_2008.pdf (accessed 14 November 2008).

3 The military have carried out policing activities with the consent of the government in Brazil, Bolivia, Honduras, El Salvador and Mexico, among others.

4 The latest Latinobarometro poll notes that, in the last few years, the tendency is for corruption to increase, not diminish; see www.latinobarometro.org/docs/INFORME_LA TINOBAROMETRO_2008.pdf (accessed 14 November 2008).

5 Source: National Criminal Data System (Sistema Nacional de Información Criminal, SNIC) of the National Directorate for Criminal Policy, National Justice and Human Rights Ministry of Argentina.

6 Citizenship here is understood in reference to social inclusion and the ability to exercise

\section{References}

Ales, Cecilia; Chillier, Gastón and Palmieri, Gustavo F. (2004) 'Illegal Practices of the Police in Argentina: Fabricated Proceedings by the Federal Police', in S. Einstein and M. Amir (eds), Police Corruption: Paradigms, Models and Concepts-Challenges for Developing Countries, The Uncertainty Series 4.1, Office of International Criminal Justice (OICJ), Texas: Sam Houston State University

Altolaguirre Larraondo, Marta (2003)

'Seguridad Ciudadana en el Hemisferio', human rights approach is based on inclusive policies that protect the rights of all citizens, in contrast to those that encourage segregation and victimisation. It seeks to tackle both crime and violence at the root, and it is based on the premise that respect for human rights is not an obstacle, but a condition to achieve security.

collective and individual rights, rather than in the more limited sense of political citizenship.

7 Unless otherwise specified, this section is based on the document Politicas Públicas y Seguridad en una Sociedad Democrática. Más Derechos, más Seguridad, which is the product of an initiative led by the Centre for Legal and Social Studies. The document was produced jointly by CELS and various other nongovernment organisations, associations, research centres and individuals.

8 This was the Plan de Protección Integral de Barrios (PPIB), part of the Argentine government's National Plan for Crime Prevention.

9 The organisations that make up this coalition are: the Centre for Legal and Social Studies (CELS) from Argentina; Conectas Direitos Humanos/Sur - Rede Universitaria de Direitos Humanos and Viva Río from Brazil; the Instituto de Defensa Legal (IDL) from Peru; the Fundación de Estudios para la Aplicación del Derecho (FESPAD) and the Washington Office on Latin America (WOLA).

10 www.oas.org/seguridad_hemisferica/ documents/rm00028e05.doc (accessed 14 November 2008).

$11 \mathrm{http}: / / \mathrm{scm}$. oas.org/doc_public/ENGLISH/ HIST_08/RM00025E04.doc (accessed 14 November 2008).

presentation for the 21 st Interdisciplinary Human Rights Course, San José, Instituto Inter-Americano de Derechos Humanos (IIDH), San José, Costa Rica, www.iidh.ed.cr/BibliotecaWeb/ PaginaExterna.aspx?url=/BibliotecaWeb/ Varios/Documentos/BD_1245745251/ altolaguirre.pdf (accessed 14 November 2008) CELS (Centro de Estudios Legales y Sociales, Centre for Legal and Social Studies) (2008) Litigio Estratégico y Derechos Humanos, La Lucha por el Derecho, Buenos Aires: CELS \& Siglo XXI 
GELS (Centro de Estudios Legales y Sociales) (2004) Informe Anual de Derechos Humanos, Buenos Aires: Siglo XXI

Chevigny, Paul (1999) 'Defining the Role of the Police in Latin America', in Juan E. Méndez; Guillermo O'Donnell and Paulo Sergio Pinheiro (eds), The (Un)rule of Law and the Underprivileged in Latin America, Notre Dame: University of Notre Dame Press

Chevigny, Paul (1995) Edge of the Knife: Police Violence in the Americas, New York: The New York Press

Dammert Lucía and Zúñiga, Liza (eds.) (2007) Seguridady Violencia: Desafios para la Ciudadanía, Buenos Aires: FLACSO

Duthie, Roger (2007) 'Introduction', in Alexander Mayer-Rieckh and Pablo de Greiff (eds), Justice as Prevention: Vetting Public Employees in Transitional Societies, New York: Social Science Research Council Garber, Carolina (2008) (In)Seguridady Violencia. Primera Aproximación a los Enfoques Teóricos y Experiencias de Políticas de Seguridad en América Latina, Documento de Trabajo, Buenos Aires: FLACSO

ICHRP (International Council on Human Rights Policy) (2003) Crime, Public Order and Human Rights, www.ichrp.org/files/summaries/ 10/114_-_Crime_Public_Order_and Human_Rights_-_English_Summary.pdf (accessed 5 May 2008)

Jelin, Elizabeth (1995) 'La Política de la Memoria: El Movimiento de Derechos Humanos y la Construcción Democrática en la Argentina', in Acuña, Carlos Hugo; González Bombal, Inés; Jelin, Elisabeth; Landi, Oscar; Quevedo, Luis Alberto; Smulovitz, Catalina; Vacchieri, Ariana (eds), Juicio, Castigos y Memorias, Buenos Aires: Nueva Visión
Kliksberg, Bernardo (2008) 'Cómo Enfrentar la Inseguridad en América Latina?', Nueva Sociedad 215: May-June

Koonings, Kees and Krujit, Dirk (1999) Societies of Fear, London: Zed Books

Méndez, Juan E. (2003) 'Justicia y Seguridad Democráticas', presentation for the 21 st Interdisciplinary Human Rights Course, San José, Instituto Inter-Americano de Derechos Humanos (IIDH), San José, Costa Rica, www.iidh.ed.cr/BibliotecaWeb/PaginaExterna. aspx?url=/BibliotecaWeb/Varios/Documentos/ BD_1245745251/mendez_1013860968.pdf (accessed 14 November 2008)

Méndez, Juan E. (1999) 'Problems of Lawless Violence: Introduction', in Juan E. Méndez; Guillermo O'Donnell and Paulo Sergio Pinheiro (eds), The (Un)rule of Law and the Underprivileged in Latin America, Notre Dame: University of Notre Dame Press

Neild, Rachel (1999) From National Security to Citizen Security, www.dd-rd.ca/site/ publications/index.php?id=1308\&subsection =catalogue (accessed 20 June 2008)

Pinheiro, Paulo Sergio (1999) 'The Rule of Law and the Underprivileged in Latin America: Introduction', in Juan E. Méndez; Guillermo O'Donnell; Paulo Sergio Pinheiro (eds), The (Un)rule of Law and the Underprivileged in Latin America, Notre Dame: University of Notre Dame Press

Pires do Rio Caldeira, Teresa (2000) City of Walls, Berkeley: University of California Press

Tiscornia, Sofía (2008) Activismo de los Derechos Humanos y Burocracias Estatales, Buenos Aires: CELS and Editores del Puerto 